\title{
PENGARUH PEMBERIAN MICRONUTRIENT SPRINKLE TERHADAP PERKEMBANGAN MOTORIK ANAK STUNTING USIA 12-36 BULAN
}

\author{
Kurnia Purwandini, Martha Irene Kartasurya ${ }^{*}$ \\ Program Studi Ilmu Gizi Fakultas Kedokteran Universitas Diponegoro \\ Jl.Dr.Sutomo No.14, Semarang, Telp (024) 8453708, Email : gizifk@undip.ac.id
}

\begin{abstract}
Background: : Stunting which caused by macronutrient and micronutrient inadequacy, is related to the increase risk of morbidity, mortality, mental and motoric developmental delays. Micronutrient sprinkle is a powder form of 16 micronutrients which developed for combating undernutrition. This study aimed to investigate the effect of sprinkle micronutrient on motor development among stunted children aged 12 to 36 months.

Method: : This supplementation study used experimental design with control group and conducted for 2 months. Subjects were stunted children aged 1 to 3 years who lived in Rowosari village, Tembalang, Semarang. Subjects were divided randomly into treatment and control groups. Micronutrient sprinkle were given to the intervention group 1 sachet for every 2 days. Treatment and control groups received nutrition conseling once every 2 weeks. Crude and fine motor development were measured by Denver Development Screening Test II at before, first, and second month after intervention.

Result: There was no differencce in age, sex, and developmental delay percentage at baseline. The percentage of crude motor developmental delay before treatment were $40 \%$ in treatment group and $42 \%$ in control group, while fine motor developmental delay were 35\% in treatment group and $38.1 \%$ in control group. At the first month after intervention, there was no change in percentage of crude motor developmental delay, but the percentage of fine motor developmental delay decrease $15 \%$ in treatment group and $33.3 \%$ in control group. At second month of intervention, the percentage of crude motor developmental delay decrease $10 \%$ in treatment group and $23.8 \%$ in control group, while the percentage of crude motor developmental delay decrease $5 \%$ in treatment group, and still $28.6 \%$ in control group.
\end{abstract}

Conclusion : Micronutrient sprinkle supplementation for 2 month decrease fine motor developmental delay

Keyword : Motor Development; Stunting; Sprinkle Micronutrient

\begin{abstract}
ABSTRAK
Latar belakang : Stunting disebabkan karena kurangnya asupan makronutien dan mikronutrien dalam jangka panjang. Stunting dapat meningkatkan risiko kesakitan, kematian, hambatan pertumbuhan mental dan motorik. Micronutrient Sprinkle adalah bubuk tabur dari 16 vitamin dan mineral, yang digunakan untuk mengatasi masalah gizi kurang. Tujuan penelitian ini untuk mengetahui pengaruh pemberian micronutrient sprinkle terhadap perkembangan motorik anak stunting 12-36 bulan

Metode: Merupakan penelitian eksperimenal dengan kontrol group yang dilakukan selama 2 bulan pada balita stunting berusia 1-3 tahun di Kelurahan Rowosari, Tembalang, Semarang. Subjek dibagi secara acak menjadi kelompok perlakuan dan kontrol. Intervensi berupa pemberian micronutrient sprinkle 2 hari sekali. Kelompok intervensi dan kontrol diberikan penyuluhan 2 minggu sekali. Perkembangan motorik kasar dan halus diukur dengan Denver Development Screening Test II pada sebelum, 1 bulan dan 2 bulan sesudah intervensi.

Hasil :Tidak ada perbedaan umur, jenis kelamin dan persen keterlambatan sebelum perlakuan. Persen keterlambatan motorik kasar sebelum perlakuan adalah $40 \%$ pada kelompok perlakuan dan $42 \%$ pada kelompok kontrol, sedangkan persen keterlambatan motorik halus adalah 35\% pada kelompok perlakuan dan 38,1\% pada kelompok kontrol. Pada satu bulan intervensi, belum terjadi penurunan persen keterlambatan motorik kasar tetapi ada penurunan persen keterlambatan motorik halus pada kelompok perlakuan menjadi 15\% sedangkan pada kelompok kontrol 33,3\%. Setelah dua bulan intervensi terjadi penurunan persentase keterlambatan motorik kasar pada kelompok perlakuan menjadi 10\%, pada kelompok kontrol 23,8\%, sedangkan persen keterlambatan motorik halus pada kelompok perlakuan menurun secara signifikan menjadi 5\% $(p=0,031)$ dan pada kelompok kontrol masih $28,6 \%$.
\end{abstract}

Simpulan : Pemberian micronutrient sprinkle selama 2 bulan, mampu menurunkan presentase keterlambatan perkembangan motorik halus secara signifikan.

Kata Kunci: Perkembangan Motorik; Stunting; Micronutrient Sprinkle

${ }^{*}$ Penulis Penanggungjawab 


\section{PENDAHULUAN}

Stunting merupakan masalah kesehatan masyarakat yang menggambarkan grafik pertumbuhan yang terhambat. Hasil Riset Kesehatan Dasar tahun 2010 menunjukkan bahwa Provinsi Jawa Tengah memiliki prevalensi stunting sebesar 33,9\% yang terdiri dari 16,9\% sangat pendek dan $17 \%$ pendek. $^{1}$ Pada tahun 2011 Kota Semarang memiliki prevalensi anak pendek $13,57 \%$ dan prevalensi untuk anaksangat pendek 7,09\%. Kecamatan Tembalang mempunyai prevalensi anak stunting tertinggi di Kota Semarang dibandingkan dengan kecamatan lain yaitu $20,08 \%$ anak pendek dan $20,08 \%{ }^{2}$

Stunting berhubungan dengan
meningkatnya risiko terjadinya kesakitan dan kematian serta terhambatnya pertumbuhan mental dan motorik., ${ }^{3,45}$ Perkembangan motorik yang terlambat mengakibatkan anak belum bisa melakukan tugas perkembangan yang sesuai dengan kelompok usianya. Periode penting dalam perkembangan motorik anak adalah tiga tahun pertama yang merupakan periode kritis kehidupan anak. ${ }^{6}$ Stunting disebabkan oleh faktor infeksi dan defisiensi makronutrien serta mikronutrien seperti besi, seng, vitamin A dan vitamin B yang berlangsung lama., ${ }^{4,5}$ Vitamin A dibutuhkan untuk pertumbuhan dan pemeliharaan kesehatan sel epitel, vitamin B berguna untuk mengoptimalkan fungsi otak dan mencegah adanya kerusakan syaraf, seng dibutuhkan untuk sintesis protein dan besi merupakan mineral utama dalam pendistribusian oksigen serta katalis dalam proses perpindahan energi ke sel. ${ }^{7}$

Micronutrient Sprinkle adalah bubuk tabur yang terdiri dari 16 vitamin dan mineral, untuk mengatasi masalah gizi kurang dan kekurangan zat gizi mikro. ${ }^{8,9}$ Kementerian Kesehatan RI bersama Pusat Teknologi Terapan dan Epidemiologi Klinik mengembangkan micronutrient sprinkle yang disesuaikan dengan masalah gizi mikro yang terjadi di Indonesia dengan nama Taburia. ${ }^{10,11}$

Penelitian mengenai pemberian vitamin maupun micronutrient sprinkle telah dilakukan di banyak negara dan mempunyai efek yang positif. ${ }^{12,13}$ Penelitian kohort di Ghana melaporkan anak berusia 12 bulan yang menerima 3 macam intervensi (micronutrient sprinkle, crushable nutritabs, fat-based nutributter) kedalam makanan sehari-hari mempunyai nilai perkembangan motorik yang lebih tinggi dibandingkan dengan anak yang tidak menerimanya. ${ }^{14}$

Penelitian mengenai pengaruh pemberian micronutrient sprinkle terhadap perkembangan motorik belum pernah dilakukan di Indonesia. Oleh karena itu, penelitian ini bertujuan untuk mengetahui pengaruh pemberian micronutrient sprinkle berpengaruh terhadap perkembangan motorik kasar dan halus anak Stunting usia 12-36 bulan di Kelurahan Rowosari, Kecamatan Tembalang, Kota Semarang.

\section{METODE PENELITIAN}

Desain penelitian yang digunakan adalah true experimental with control group. ${ }^{15}$ Subjek penelitian ini adalah anak stunting berusia 12-36 bulan di Kelurahan Rowosari, Kecamatan Tembalang, Kota Semarang, dengan kriteria inklusi subjek tidak memiliki kelainan bawaan dan tidak memiliki riwayat penyakit kronis. Subjek sejumlah 44 orang dibagi secara random menjadi 2 kelompok, yaitu kelompok perlakuan dan kelompok kontrol. Tiga subjek drop out dalam penelitian ini, sehingga total subjek penelitian yang dianalisis adalah 41 subjek.

Variabel bebas dalam penelitian ini adalah kelompok perlakuan dan kontrol. Kelompok perlakuan diberi mikronutrient sprinkle 2 hari sekali dengan dosis $5 \mathrm{gr}$ ( 1 sachet) selama 2 bulan intervensi serta dilakukan penyuluhan 2 minggu sekali untuk memotivasi ibu maupun pengasuh agar memberikan asupan makanan yang seimbang dan pola asuh yang baik kepada anak. Kelompok kontrol tidak diberikan mikronutrient sprinkle, tetapi diberikan penyuluhan yang sama 2 minggu sekali. Micronutrient sprinkle berisi vitamin A $(417 \mu \mathrm{cg})$, vitamin C (30mg), vitamin D $(5 \mu \mathrm{cg})$, vitamin $\mathrm{E}(6 \mathrm{mg})$, vitamin $\mathrm{K}(20 \mu \mathrm{cg})$, tiamin $(0,5 \mathrm{mg})$, riboflavin $(0,5 \mathrm{mg})$, piridoksin $(0,5 \mathrm{mg})$, niasin $(5 \mathrm{mg})$, kobalamin $(1 \mu \mathrm{cg})$, asam folat $(150 \mu \mathrm{cg})$, asam pantotenat $(3 \mathrm{mg})$, yodium $(50 \mu \mathrm{cg})$, seng $(5 \mathrm{mg})$, zat besi $(10 \mathrm{mg})$ dan selenium $(20 \mu \mathrm{cg})$. Formulir kepatuhan digunakan untuk mengetahui kepatuhan subjek dalam mengkonsumsi mikronutrient sprinkle pada kelompok perlakuan.

Variabel terikat adalah perkembangan motorik. Perkembangan motorik kasar dan halus diukur pada sebelum, 1 bulan dan 2 bulan sesudah intervensi dengan menggunakan formulir Denver Development Screening Test II (DDST II) yang disesuaikan dengan umur responden. Pengukuran perkembangan motorik dilakukan oleh mahasiswa psikologi Universitas Diponegoro Semarang. Hasil ukur dikategorikan keterlambatan, bila didapatkan $\geq 2$ keterlambatan dan dikategorikan normal jika hanya terdapat satu keterlambatan. ${ }^{16}$

Variabel perancu yang diteliti adalah pola asuh, kejadian sakit serta asupan energi, protein, besi dan seng. Pola asuh diukur pada sebelum 
perlakuan oleh peneliti, melalui wawancara dengan kuesioner yang terdiri dari 15 pertanyaan mengenai praktek dalam mengasuh anak dalam memberikan rangsangan mental yang mempengaruhi perkembangan motorik anak..$^{17,18}$ Data frekuensi sakit diare dan ISPA (infeksi saluran pernafasan atas) diperoleh melalui formulir morbiditas yang diisi setiap minggunya oleh peneliti selama penelitian berlangsung. Data asupan energi, protein, seng dan besi yaitu jumlah total energi, protein, mineral seng dan besi yang diperoleh dari food recall $3 \times 24$ pada sebelum dan selama intervensi.

Persen Keterlambatan perkembangan motorik antara kelompok kontrol dan perlakuan diuji dengan chi square, sedangkan perbandingan perkembangan motorik sebelum, 1 bulan dan 2 bulan sesudah perlakuan diuji dengan Mac Nemar. Data pola asuh, kejadian sakit, asupan energi, protein, besi dan seng diuji normalitasnya menggunakan uji Saphiro-Wilk. Perbandingan ratarata asupan energi, protein, besi, seng, serta presentase pola asuh dan hari sakit ISPA antara kelompok kontrol dan perlakuan dilakukan dengan uji independent t-test untuk data berdistribusi normal, atau Mann Whitney untuk data berdistribusi tidak normal. Tingkat Kecukupan energi dan protein kedua pada masing-masing kelompok antara sebelum, setelah 1 bulan intervensi dan setelah 2 bulan intervensi dilakukan uji ANOVA. Pengujian dilakukan dengan tingkat signifikansi $(\alpha)$ 0,05 dan tingkat kepercayaan $95 \% .^{15}$

\section{HASIL PENELITIAN \\ Karakteristik Subjek}

Hasil uji beda menunjukkan tidak ada perbedaan jenis kelamin dan usia antara dua kelompok. Subjek pada awal penelitian ini berjumlah 22 orang pada masing-masing kelompok. Tiga subjek drop out dalam penelian ini, dua subjek dari kelompok perlakuan (1 subjek sakit dan 1 subjek tidak mengkonsumsi taburia secara rutin) dan satu subjek dari kelompok kontrol (1 subjek tidak bersedia diukur perkembangan motoriknya setelah satu bulan intervensi). Dua subjek drop out dari kelompok perlakuan berjenis kelamin perempuan, sedangkan satu subjek drop out dari kelompok kontrol berjenis kelamin lakilaki. Karakteristik subjek (umur dan jenis kelamin) dapat dilihat pada Tabel 1.

Tabel 1. Karakteristik subjek

\begin{tabular}{lccccccc}
\hline Karakteristik subjek & $\begin{array}{c}\text { Perlakuan } \\
(\mathbf{n = 2 0})\end{array}$ & $\begin{array}{c}\text { Kontrol } \\
(\mathbf{n = 2 1})\end{array}$ & Total & $\boldsymbol{p}^{*}$ \\
\hline Umur (Median \pm SD) & $23,3 \pm 6,70$ & \multicolumn{2}{c}{$24,4 \pm 6,51$} & & - & 0,380 \\
$\quad$ Bulan & $\mathbf{N}$ & $\mathbf{\%}$ & $\mathbf{N}$ & $\mathbf{\%}$ & $\mathbf{N}$ & $\mathbf{\%}$ & \\
\hline Jenis kelamin & 13 & 37,1 & 8 & 38,1 & 21 & 100 & 0,085 \\
$\quad$ laki- laki & 7 & 35,0 & 13 & 61,9 & 20 & 100 & \\
$\quad$ perempuan & & &
\end{tabular}

*uji chi square

\begin{abstract}
Distribusi Persen Fase Keterlambatan 30\%. Penurunan persen keterlambatan Perkembangan Motorik Halus pada Masing- perkembangan motorik halus kelompok kontrol masing Kelompok

Penurunan persen keterlambatan perkembangan motorik halus kelompok perlakuan pada sebelum dan 1 bulan intervensi sebesar $20 \%$, serta pada sebelum dan 2 bulan intervensi sebesar pada sebelum dan 1 bulan intervensi hanya sebesar $4,8 \%$, serta pada sebelum dan 2 bulan intervensi hanya $9,5 \%$. Persen keterlambatan perkembangan motorik halus pada kelompok perlakuan dan kontrol disajikan pada Tabel 2.
\end{abstract}

Tabel 2. Persen keterlambatan motorik halus pada kelompok perlakuan dan kontrol

\begin{tabular}{|c|c|c|c|c|c|c|}
\hline & \multicolumn{2}{|c|}{ Kelompok perlakuan } & \multirow[b]{2}{*}{$p^{*}$} & \multicolumn{2}{|c|}{ Kelompok kontrol } & \multirow[b]{2}{*}{$p^{*}$} \\
\hline & $\mathbf{n}$ & $\begin{array}{c}\% \\
\text { keterlambatan }\end{array}$ & & $\mathbf{n}$ & $\begin{array}{c}\% \\
\text { keterlambatan }\end{array}$ & \\
\hline Sebelum perlakuan & 7 & $35 \%$ & \multirow{2}{*}{0,219} & 8 & $38,1 \%$ & \multirow{2}{*}{1,000} \\
\hline 1 bulan setelah perlakuan & 3 & $15 \%$ & & 7 & $33,3 \%$ & \\
\hline Sebelum perlakuan & 7 & $35 \%$ & \multirow{2}{*}{0,070} & 8 & $38,1 \%$ & \multirow{2}{*}{0,687} \\
\hline 2 bulan setelah & 1 & $5 \%$ & & 6 & $28,6 \%$ & \\
\hline
\end{tabular}




\author{
perlakuan \\ *uji Mac Nemar
}

Persen keterlambatan perkembangan motorik kasar pada kelompok perlakuan dan kontrol disajikan pada Tabel 3.

Tabel 2. Persen keterlambatan motorik kasar pada kelompok perlakuan dan kontrol

\begin{tabular}{|c|c|c|c|c|c|c|}
\hline & \multicolumn{2}{|c|}{ Kelompok perlakuan } & \multirow[b]{2}{*}{$p^{*}$} & \multicolumn{2}{|c|}{ Kelompok kontrol } & \multirow[b]{2}{*}{$p^{*}$} \\
\hline & $\mathbf{n}$ & $\begin{array}{c}\% \\
\text { keterlambatan }\end{array}$ & & $\mathbf{n}$ & $\begin{array}{c}\% \\
\text { keterlambatan }\end{array}$ & \\
\hline Sebelum perlakuan & 8 & $40 \%$ & \multirow{2}{*}{1,000} & 9 & $42,5 \%$ & \multirow{2}{*}{1,000} \\
\hline 1 bulan setelah perlakuan & 8 & $40 \%$ & & 9 & $42,5 \%$ & \\
\hline Sebelum perlakuan & 8 & $40 \%$ & \multirow[b]{2}{*}{0,031} & 9 & $42,5 \%$ & \multirow[b]{2}{*}{0,219} \\
\hline $\begin{array}{l}2 \text { bulan setelah } \\
\text { perlakuan }\end{array}$ & 2 & $10 \%$ & & 5 & $23,8 \%$ & \\
\hline
\end{tabular}

"uji Mac Nemar

Persen keterlambatan perkembangan motorik kasar kelompok perlakuan belum terjadi penurunan setelah 1 bulan intervensi. Setelah 2 bulan intervensi terjadi penurunan persen keterlambatan perkembangan motorik kasar sebesar 30\%. Persen keterlambatan perkembangan motorik kasar kelompok kontrol juga belum terjadi penurunan setelah 1 bulan intervensi. Setelah 2 bulan intervensi, penurunan persen keterlambatan perkembangan motorik kasar sebesar $25,1 \%$. Jadi ada penurunan persen keterlambatan motorik kasar pada kedua kelompok di bulan kedua intervensi, tetapi penurunan persen keterlambatan motorik kasar pada kelompok perlakuan lebih besar dibandingkan kelompok kontrol.

Distribusi Persen Fase Keterlambatan Perkembangan Motorik Halus dan Motorik Kasar

Persen keterlambatan motorik halus dan kasar pada kelompok perlakuan dan kontrol disajikan pada Tabel 4.

Tabel 4. Persen keterlambatan perkembangan motorik halus dan motorik kasar

\begin{tabular}{|c|c|c|c|c|c|c|}
\hline & \multicolumn{3}{|c|}{$\begin{array}{c}\text { \% keterlambatan } \\
\text { Perkembangan motorik } \\
\text { kasar }\end{array}$} & \multicolumn{3}{|c|}{$\begin{array}{c}\text { \% keterlambatan } \\
\text { Perkembangan motorik } \\
\text { halus }\end{array}$} \\
\hline & $\begin{array}{c}\text { Perlakuan } \\
(\mathbf{n}=20)\end{array}$ & $\begin{array}{c}\text { Kontrol } \\
(\mathrm{n}=21)\end{array}$ & $p^{*}$ & $\begin{array}{c}\text { Perlakuan } \\
(\mathbf{n}=20)\end{array}$ & $\begin{array}{c}\text { Kontrol } \\
(\mathbf{n}=\mathbf{2 1})\end{array}$ & $p^{*}$ \\
\hline $\begin{array}{l}\text { Sebelum perlakuan } \\
\text { jumlah (n) } \\
\text { persen }(\%)\end{array}$ & $\begin{array}{c}8 \\
40 \% \\
\end{array}$ & $\begin{array}{c}9 \\
43,9 \% \\
\end{array}$ & 0,837 & $\begin{array}{c}7 \\
35 \% \\
\end{array}$ & $\begin{array}{c}8 \\
38,1 \% \\
\end{array}$ & 0,853 \\
\hline $\begin{array}{l}1 \text { bulan setelah } \\
\text { perlakuan } \\
\qquad \begin{array}{l}\text { jumlah }(\mathrm{n}) \\
\text { persen }(\%)\end{array}\end{array}$ & $\begin{array}{c}8 \\
40 \%\end{array}$ & $\begin{array}{c}9 \\
43,9 \%\end{array}$ & 0,277 & $\begin{array}{c}3 \\
15 \%\end{array}$ & $\begin{array}{c}7 \\
33,3 \%\end{array}$ & 0,853 \\
\hline $\begin{array}{l}2 \text { bulan setelah } \\
\text { perlakuan } \\
\qquad \begin{array}{l}\text { jumlah }(\mathrm{n}) \\
\text { persen }(\%)\end{array}\end{array}$ & $\begin{array}{c}2 \\
10 \%\end{array}$ & $\begin{array}{c}5 \\
23,8 \%\end{array}$ & 0,093 & $\begin{array}{c}1 \\
5 \%\end{array}$ & $\begin{array}{c}6 \\
28,6 \%\end{array}$ & 0,240 \\
\hline
\end{tabular}

"uji chi square

Pada sebelum perlakuan, terdapat 8 subjek pada kelompok perlakuan dan 9 subjek pada kelompok kontrol yang mengalami keterlambatan perkembangan motorik kasar. Sedangkan pada perkembangan motorik halus, terdapat 7 subjek 
pada kelompok perlakuan dan 8 subjek pada kelompok kontrol yang mengalami keterlambatan.

Pada 1 bulan setelah intervensi, belum terjadi penurunan jumlah subjek yang mengalami keterlambatan perkembangan motorik kasar pada kelompok perlakuan maupun kontrol. Pada perkembangan motorik halus, terjadi penurunan keterlambatan perkembangan motorik kasar pada kelompok perlakuan menjadi 3 subjek dan 7 subjek pada kelompok kontrol.

Pada 2 bulan setelah intervensi, terjadi penurunan jumlah subjek yang mengalami keterlambatan perkembangan motorik kasar pada kelompok perlakuan menjadi 2 subjek dan pada kelompok kontrol 5 subjek. Pada perkembangan motorik halus, terjadi penurunan keterlambatan perkembangan motorik halus pada kelompok perlakuan menjadi 1 subjek, dan pada kelompok kontrol masih terdapat 6 subjek yang mengalami keterlambatan perkembangan motorik halus. Dapat disimpulkan bahwa pada 2 bulan setelah intervensi terjadi penurunan persen keterlambatan motorik kasar dan halus pada kelompok perlakuan.

\section{Rata-rata Asupan Besi, Seng, Energi dan Protein pada Kelompok Perlakuan dan Kelompok Kontrol}

Angka Kecukupan Gizi (AKG) mineral besi dan seng adalah $8 \mathrm{mg} /$ hari, asupan besi dan seng subjek penelitian pada sebelum, 1 bulan dan 2 bulan intervensi masih dibawah AKG, sehingga asupan asupan mineral besi dan seng subjek penelitian dikategorikan masih rendah. Prosentase rata-rata asupan energi dan protein subjek penelitian dikategorikan cukup (90-110\%) dan lebih $(\geq 110 \%)$. Tidak ada perbedaan peningkatan asupan energi dan protein kelompok perlakuan dan kontrol pada sebelum dan 2 bulan intervensi. Tidak ada perbedaan rata-rata asupan besi, seng, energi dan protein pada kelompok perlakuan dan kontrol, sehingga rata-rata asupan besi, seng, energi dan protein bukan merupakan variabel pengganggu pada penelitian ini. Rata-rata asupan besi, seng, energi dan protein pada kelompok perlakuan dan kontrol dapat dilihat pada Tabel 6.

Tabel 6. Rata-rata Asupan Besi, Seng, Energi dan Protein pada Kelompok Perlakuan dan Kontrol

\begin{tabular}{|c|c|c|c|}
\hline & $\begin{array}{c}\text { Perlakuan }(\mathrm{n}=20) \\
\text { Mean + SD }\end{array}$ & $\begin{array}{c}\text { Kontrol (n=21) } \\
\text { Mean + SD }\end{array}$ & $\boldsymbol{P}$ \\
\hline \multicolumn{4}{|l|}{ Rata-rata asupan besi (mg) } \\
\hline Sebelum & $3,6 \pm 2,06$ & $3,1 \pm 2,52$ & $0,200^{* *}$ \\
\hline 1 bulan & $3,9 \pm 1,88$ & $3,1 \pm 2,06$ & $0,781^{*}$ \\
\hline 2 bulan & $4,0 \pm 1,78$ & $3,3 \pm 2,60$ & $0.078^{* *}$ \\
\hline \multicolumn{4}{|l|}{ Rata-rata asupan seng (mg) } \\
\hline Sebelum & $2,7 \pm 0,894$ & $2,4 \pm 1,34$ & $0,406^{*}$ \\
\hline 1 bulan & $3,0 \pm 1,03$ & $2,5 \pm 1,32$ & $0,154^{*}$ \\
\hline 2 bulan & $3,5 \pm 1,37$ & $3,6 \pm 2,06$ & $0,239^{* *}$ \\
\hline \multicolumn{4}{|l|}{ Rata-rata asupan energi (\%) } \\
\hline Sebelum & $95,5 \pm 21,51$ & $98,6 \pm 32,68$ & $0,729^{*}$ \\
\hline 1 bulan & $110,7 \pm 22,20$ & $103,7 \pm 43,12$ & $0,515^{*}$ \\
\hline 2 bulan & $114,4 \pm 21,21$ & $105,9 \pm 37,8$ & $0,379^{*}$ \\
\hline $\begin{array}{c}\text { Peningkatan asupan energi } 2 \\
\text { bln }\end{array}$ & $18,3 \pm 1,9$ & $7,3 \pm 2,7$ & $0,144^{* *}$ \\
\hline \multicolumn{4}{|l|}{$\begin{array}{c}\text { Rata-rata asupan protein } \\
(\%)\end{array}$} \\
\hline Sebelum & $111,7 \pm 37,41$ & $110,6 \pm 46,5$ & $0,967^{*}$ \\
\hline 1 bulan & $131,2 \pm 40,42$ & $118,4 \pm 59,16$ & $0,425^{*}$ \\
\hline 2 bulan & $113,4 \pm 34,76$ & $119,9 \pm 58,19$ & $0,376^{*}$ \\
\hline $\begin{array}{c}\text { Peningkatan asupan protein } 2 \\
\mathrm{bln}\end{array}$ & $21,6 \pm 2,6$ & $9,3 \pm 4,4$ & $0,287^{*}$ \\
\hline
\end{tabular}


Perbedaan Tingkat Kecukupan Energi dan Protein pada Sebelum dan Setelah Intervensi Antara Kelompok Perlakuan dan Kontrol
Perbedaan tingkat kecukupan energi dan protein pada sebelum dan setelah intervensi antara kelompok perlakuan dan kontrol disajikan dalam Tabel 7.

Tabel 7. Tingkat Kecukupan Energi dan Protein Sebelum dan Setelah Intervensi

\begin{tabular}{ccccc}
\hline Variabel & \multicolumn{2}{c}{ Perlakuan $(\mathbf{n}=\mathbf{2 0})$} & \multicolumn{2}{c}{ Kontrol $(\mathbf{n = 2 1})$} \\
\cline { 2 - 5 } & Mean \pm SD & $\boldsymbol{p}$ & Mean \pm SD & $\boldsymbol{P}$ \\
\hline Tingkat kecukupan & & & & \\
energi & $96,1 \pm 21,9$ & & $98,6 \pm 32,7$ & \\
Sebelum & $110,9 \pm 22,1$ & $0,024^{*}$ & $103,8 \pm 43,1$ & $0,815^{*}$ \\
1 bulan & $114,5 \pm 21,2$ & & $105,9 \pm 37,8$ & \\
2 bulan & & & & \\
\hline Tingkat kecukupan & & & $110,6 \pm 46,6$ & \\
protein & $111,8 \pm 37,8$ & & $118,4 \pm 59,2$ & $0,841^{*}$ \\
Sebelum & $132,6 \pm 22.34$ & $0,129^{*}$ & $119,9 \pm 58,2$ & \\
1 bulan & $133,4 \pm 34,8$ & & & \\
2 bulan & & & &
\end{tabular}

Pada kelompok perlakuan yang diberikan micronutrient sprinkle, terdapat perbedaan tingkat kecukupan energi $(p=0,024)$ antara sebelum dengan 1 bulan intervensi $(p=0,036)$ dan antara sebelum dengan 2 bulan intervensi $(p=0,010)$. Tingkat kecukupan protein kelompok perlakuan tidak terdapat perbedaan. Pada kelompok kontrol, tingkat kecukupan energi dan protein tidak terjadi perbedaan yang signifikan.

\section{Pola Asuh dan Kejadian ISPA pada Kelompok Perlakuan dan Kontrol}

Data kejadian sakit pada penelitian ini adalah ISPA (infeksi saluran pernafasan atas) data diare tidak dianalisis karena hanya ada 2 anak yang diare selama 1 hari (1 anak pada kelompok kontrol dan 1 anak pada kelompok perlakuan). Kejadian ISPA dan pola asuh pada kelompok perlakuan dan kontrol pada 2 bulan penelitian disajikan dalam Tabel 8.

Tabel 8. Deskripsi Variabel Kontrol (Pola Asuh dan Presentase Hari Sakit ISPA)

\begin{tabular}{lccccc}
\hline & \multicolumn{2}{c}{ Kelompok perlakuan } & \multicolumn{2}{c}{ Kelompok kontrol } & \multirow{2}{*}{${ }^{*}$} \\
\cline { 2 - 6 } & $\mathbf{n}$ & mean \pm SD & n & mean \pm SD & \\
\hline Prosentase pola asuh & 20 & $71,0 \pm 19,58$ & 21 & $66,9 \pm 17,64$ & 0,568 \\
\hline Prosentase hari sakit ISPA & 20 & $10,0 \pm 6,79$ & 21 & $11,0 \pm 6,43$ & 0,837 \\
\hline
\end{tabular}
*uji independent $t$-test

Tidak ada perbedaan pola asuh dan kejadian ISPA antara kelompok perlakuan dan kelompok kontrol, sehingga pola asuh dan kejadian ISPA bukan merupakan variabel pengganggu pada penelitian ini.

\section{PEMBAHASAN}

Stunting berhubungan dengan resiko terhambatnya pertumbuhan motorik kasar maupun halus, karena pada anak stunting terjadi perubahan struktur dan fungsi dalam perkembangan otak karena adanya keterlambatan kematangan sel-sel saraf di bagian cerebellum. Cerebellum merupakan otak kecil, yang merupakan pusat koordinasi gerak motorik. Keterlambatan kematangan sel-sel saraf di bagian cerebellum karena adanya penurunan jumlah mielin, dendrite kortikal dalam medulla spinalis, serta reduksi sinapsis neurotransmitter. ${ }^{19,20}$ Motorik halus adalah gerakan yang menggunakan otot-otot halus, seperti memindahkan benda dari tangan, mencoret-coret, dan menyusun balok. ${ }^{21}$ Motorik kasar adalah gerakan tubuh yang menggunakan otot-otot besar seperti menendang, berlari, dan naik turun tangga. ${ }^{21}$ Kedua perkembangan motorik tersebut sangat dipengaruhi oleh stimulasi, kesehatan dan gizi. ${ }^{22}$ Kedua kelompok mendapatkan penyuluhan mengenai pentingnya asupan gizi yang seimbang, serta pola asuh untuk memberikan stimulasi yang 
baik untuk anak. Perkembangan motorik yang terlambat berarti anak usia tertentu anak belum bisa melakukan tugas perkembangan yang sesuai dengan kelompok usianya, tetapi anak akan mampu melakukan tugas perkembangannya jika diberi stimulasi dan gizi yang baik. ${ }^{21}$ Stimulasi mampu merangsang kemampuan dasar anak, meningkatkan percabangan dendrit dan jumlah serabut dendrit dalam otak, sehingga mampu meningkatkan koneksi dendit yang secara tidak langsung berdampak pada peningkatan perkembangan motorik. ${ }^{23,24}$

Pada penelitian ini, di kedua kelompok terjadi penurunan persen keterlambatan perkembangan motorik, tetapi penurunan persen keterlambatan pada kelompok perlakuan yang diberikan micronutrient sprinkle lebih besar dibandingkan kelompok kontrol. Penurunan persen keterlambatan motorik kasar dan motorik halus yang besar pada kelompok perlakuan dikarenakan pemberian micronutrient sprinkle 2 hari sekali selama 2 bulan. Menurut penelitian di Jamaika, anak stunting mempunyai tingkat aktifitas yang rendah dibanding dengan anak yang tidak stunting, dan tingkat aktifitas rendah berhubungan dengan keterlambatan perkembangan motorik. Jika anak stunting mampu meningkatkan tingkat aktifitasnya, maka pada akhirnya perkembangan motorik pada anak stunting tidak akan ada beda dibanding anak yang tidak stunting, karena peningkatan tingkat aktifitas berujung pada pengejaran keterlambatan perkembangan anak tersebut. ${ }^{25}$ Pemberian micronutrient sprinkle secara tidak langsung berpengaruh terhadap peningkatan struktur dan fungsi dalam perkembangan otak, peningkatan tingkat aktifitas pada anak dan penurunan keterlambatan perkembangan motorik.

Menurut penelitian pada anak usia 6-12 bulan di Bangladesh, suplementasi mikronutrient sprinkle setiap minggu selama 6 bulan mampu meningkatkan perkembangan motorik dibanding anak yang hanya menerima suplementasi besi atau seng saja. ${ }^{26}$ Hal tersebut dikarenakan kandungan vitamin dan mineral dalam mikronutrient sprinkle secara tidak langsung berpengaruh terhadap peningkatan perkembangan motorik.

Mineral besi dan seng berperan dalam metabolisme energi di sel dan neuron, mielinieasasi, metabolisme dopamine dan neurotransmitter. Defisiensi seng menyebabkan berkurangnya tingkat aktifitas dan retardasi pertumbuhan. Defisiensi besi berhubungan dengan penurunan aktifitas pada anak dan hypomyelination, karena defisiensi besi pada anak menyebabkan keletihan, keragu-raguan, ketakutan dan kelelahan. Vitamin A berperan dalam metabolisme besi dan seng. Vitamin $\mathrm{C}$ membantu absorbsi besi. ${ }^{28}$

Vitamin A berperan penting dalam perkembangan, karena vitamin A berperan dalam penglihatan dan pemeliharaan sel epitel. Asupan vitamin A yang cukup juga mampu meningkatkan level tembaga di plasma darah, tembaga sangat berperan dalam perkembangan otak karena mampu meningkatkan aktifitas otak. ${ }^{28}$

Vitamin B6 berperan dalam pengembangan sistem saraf pusat dan mempengaruhi perkembangan otak. Kekurangan vitamin B6 mengubah fungsi $N$-methyl-D-aspartate receptors, sebuah reseptor dalam neurotransmitter. ${ }^{28}$

Riboflavin berperan penting dalam metabolisme penghasil energi karena meyediakan gugus-gugus reaktif koenzim flavin mononukleotida (FMN) dan flavin adenin dinukleotida (FAD), kedua koenzim ini bekerja sebagai pembawa hidrogen dalam sistem oksidatif mitokondria, sehingga mencegah kekurangan energi pada anak dan secara tidak langsung mampu mencegah penurunan eksplorasi pada anak..$^{27,28}$ Kalium mampu meningkatkan transmisi saraf serta kontraksi otot. Kekurangan kalium menyebabkan lemah otot. ${ }^{28}$

Pada penelitian ini dilakukan penyuluhan 2 minggu sekali pada kedua kelompok, untuk memotivasi ibu maupun pengasuh agar memberikan asupan makanan yang seimbang serta meningkatkan asupan energi dan protein. Pada kelompok perlakuan, terdapat peningkatan tingkat kecukupan energi pada sebelum dan 1 bulan, serta sebelum dan 2 bulan, hal ini tidak terjadi pada kelompok kontrol. Peningkatan nafsu makan yang terjadi dikarenakan pemberian micronutrient sprinkle. $^{29}$ Asupan seng yang tercukupi mampu meningkatkan nafsu makan, karena mineral seng meningkatkan ketajaman indra perasa. ${ }^{30}$

Energi dan protein berperan dalam proliferasi, diferensiasi sel, dan mempengaruhi neurotransmitter. ${ }^{31}$ Asupan energi yang baik mampu meningkatkan tingkat aktivitas fisik, karena otot-otot tubuh dan sistem penunjang tidak kekurangan energi saat melakukan aktifitas fisik maupun metabolisme gerak. Protein mengandung asam amino tirosin yang merupakan penyusun neurotransmitter dopamine yang berperan dalam menghantarkan impuls saraf sehingga mempengaruhi perkembangan otak. ${ }^{32}$ Kekurangan protein menyebabkan otot-otot berkurang dan lemah, karena jaringan adiposa berkurang. 
Jaringan adiposa tidak memerankan peranannya secara sentral, karena pada kondisi defisiensi gizi, tubuh memberikan batasan pada pertumbuhan jaringan adiposa, ini yang menyebabkan menurunnya tingkat aktivitas pada anak yang berujung pada keterlambatan perkembangan motorik. ${ }^{33,34}$ Asupan energi dan protein pada kedua kelompok penelitian digolongkan cukup (90$110 \%$ ) bahkan ada beberapa subjek digolongkan lebih $(\geq 110 \%){ }^{35}$ Dalam food recall subjek lebih sering jajan dibandingkan makan makanan pokok, buah atau sayur

Tidak ada perbedaan presentase asupan energi dan protein antara kedua kelompok pada sebelum, 1 dan 2 bulan setelah intervensi. Tidak terdapat perbedaan rata-rata presentase asupan energi yang signifikan antara kelompok perlakuan dan kontrol, walaupun terdapat peningkatan asupan energi antara sebelum dengan 1 dan 2 bulan setelah intervensi pada kelompok perlakuan. Tidak ada perbedaan pada peningkatan protein pada sebelum dan 2 bulan setelah intervensi antara 2 kelompok.

Pada penelitian ini tidak terdapat perbedaan rata-rata asupan besi dan seng antara kelompok perlakuan dan kontrol pada sebelum, 1 dan 2 bulan setelah intervensi. Kecukupan besi dan seng pada balita usia 1-3 tahun yaitu $8 \mathrm{mg} .{ }^{36}$ Berdasarkan hasil food recall $24 \mathrm{jam}$, rata-rata kecukupan besi dan seng kelompok perlakuan dan kontrol masih dibawah Angka Kecukupan Gizi (AKG) pada sebelum maupun sesudah perlakuan. Kecukupan besi dan seng hanya tercukupi tidak lebih dari setengah $\mathrm{AKG}$, hal ini menunjukkan tepatnya pemberian micronutrient sprinkle, dikarenakan adanya defisiensi zat gizi mikro. Micronutrient sprinkle yang diberikan 2 hari sekali berkontribusi sebanyak $5 \mathrm{mg}$ besi serta $2,5 \mathrm{mg}$ setiap harinya, sehingga mampu mencukupi kebutuhan mineral seng dan besi, serta secara tidak langsung mampu mengejar keterlambatan perkembangan motorik pada kelompok perlakuan.

Pola asuh yang baik sangat penting peranannya karena mempengaruhi tumbuh kembang anak. Anak yang diasuh dengan baik dapat lebih berinteraksi secara positif dibandingkan dengan anak yang tidak diasuh dengan baik. ${ }^{36}$ Pada penelitian ini tidak terdapat perbedaan pola asuh yang signifikan pada kelompok perlakuan dan kontrol, walaupun ratarata pola asuh pada kelompok perlakuan lebih tinggi. Rata-rata pola asuh pada kelompok perlakuan adalah $71 \%$ dan pada kelompok kontrol adalah $66,9 \%$.
Kejadian infeksi saluran pernafasan atas (ISPA) pada kelompok perlakuan dan kontrol tidak menunjukkan perbedaan yang bermakna. Pada kelompok perlakuan rata-rata sakit yaitu 10 hari dan pada kelompok kontrol yaitu 11 hari. Tingkat pendidikan orang tua kedua kelompok rata-rata lulus SMA dan tingkat sosial ekonomi kedua kelompok mayoritas menengah kebawah. Pada penelitian ini hanya terdapat 4 subjek yang pengikuti Pendidikan Anak Usia Dini (PAUD), satu subjek pada kelompok perlakuan dan tiga subjek pada kelompok kontrol, sehingga PAUD bukan merupakan variabel pengganggu dalam penelitian ini.

\section{KETERBATASAN PENELITIAN}

Instrumen pengukuran perkembangan motorik yang tepat menggunakan Bayley Scales of Infant and Toddler Development Test, tetapi karena ada keterbatasan dana, maka pada penelitian ini pengukuran perkembangan motorik dilakukan dengan Denver Development Screening Test II (DDST II). DDST II digunakan untuk skrining keterlambatan pada anak usia 1 bulan hingga 6 tahun.

\section{SIMPULAN}

Pemberian micronutrient sprinkle selama 2 bulan mampu menurunkan presentase keterlambatan perkembangan motorik halus pada anak stunting usia 12 hingga 36 bulan.

\section{SARAN}

Balita stunting dianjurkan untuk mengkonsumsi micronutrient sprinkle (taburia) karena dapat membantu meningkatkan perkembangan motorik.

\section{DAFTAR PUSTAKA}

1. Badan Penelitian Dan Pengembangan Kesehatan Kementerian Kesehatan RI. Riset kesehatan dasar 2010. Laporan Nasional. 2010. p 26, 29, 30.

2. Dinas Kesehatan Kota Semarang. Data Seksi Gizi Dinas Kesehatan Kota Semarang 2010. Semarang : Dinas Kesehatan Kota Semarang. 2010.

3. Gunarma D, Singgih. Dasar dan Teori Perkembangan Anak. PT BPK Gunung Mulia.

4. Waterlow JC, Schurch B. Cause and Mechanism of Linear Growth Retardation. Eur J Clin Nutr 1994; 48: S1-S216.

5. Shrimpton, Victoria CG, de Onis M, Lima RC, Blossner M, Clugston G. Worldwide timing of growth faltering: implications for nutritional interventions. Pediatrics 2001; 107: e75. 
6. Soetjiningsih. Tumbuh kembang anak. Jakarta: Penerbit Buku Kedokteran EGC. 1995.

7. L Kathleen Mahan and Sylvia Escott-Stump. Krause's Food and Nutrition Therapy. Canada: Saunders Elsevier. 2008.

8. Stanley H Zlotkin, Claudia Schauer, Anna Christofides, dkk. Micronutrient Sprinkles to Control Childhood Anaemia. PloS Medicine; Volume 2. 2005.

9. Micronutrient powder use and outcomes in refugee camps in Nepal (ASIA). UNHCR-The UN Refugee Agency. 2009.

10. Direktorat Bina Gizi Masyarakat. Apa dan Mengapa Tentang Taburia; panduan Praktis bagi kader. Dijen Binkesmas-kemenkes RI, Jakarta. 2010.

11. Departemen Kesehatan RI. Pengembangan Taburia. 2011. Available from: http://gizi.depkes.go.id/artikel/pengembangantaburia/.

12. Harapap, AB jahari, MA husaini. Effect of an Energi and Micronutrient Supplement on Motor Development and Motor Activity in Undernourished Children in Indonesia. Europan Journal of Clinical Nutrition.2000.

13. H Harapap, AB jahari, MA husaini. Effect of an Energi and Micronutrient Supplement on Iron Deficiency Anemia, Physical Activity and Motor and Mental Development in Undernourished Children in Indonesia. Europan Journal of Clinical Nutrition.2000.

14. Seth Adu-Afarwuah, Anna Lartey, Kenneth H Brown, Stanley Zlotkin, André Briend and Kathryn G Dewey. Author Randomized Comparison of 3 Types of Micronutrient Supplements for Home Fortification of Complementary Foods in Ghana: Effects on Growth and Motor Development. American Journal of Clinical Nutrition, Vol. 86, No. 2, 412 420, August 2007.

15. Dahlan S. Statistik untuk Kedokteran dan Kesehatan. Jakarta-Salemba Medika; 2008.

16. WilliamFranskenburg. The Denver Developmental Screening Test. The Journal of Pediatrics71 (2):181-191. University of Colorado Medical Center. 1973.

17. L.K. Zottarelli, T.S. Sunil and S. Rajaram. Influence of Parental and Socioeconomic Factors on Stunting in Children under 5 years in Egypt. 2007.

18. Susan P. Walker and Susan M. Chang. Early Childhood Stunting Is Associated with Poor Psychological Functioning in Late Adolescence and Effects Are Reduced by Psychosocial Stimulation. The Journal of Nutrition. 2007.

19. Levitsky DA, Strupp BJ. Malnutrition and The Brain: Changing Concepts, Changing Concerns. J Nutr. 1995; 74:381-6.
20. Udani PM. Brain and Various Facets of Child Development. Indian J Pediatrict. 1992, 59; 165186.

21. Lita D Astari, Amini Nasoetion, Cesilia M Dwiriani. Hubungan Karakteristik Keluarga, Pola pengasuhan dan Kejadian stunting anak usia 6-12 bulan. Bogor: Departemen gizi masyarakat, FEMA-IPB. 2005.

22. Physical development in infancy. Exploring Lifespan Development: International Edition. Laura E. Berk, Illinois State University. 2010.

23. Restivo L, Ferrari F, Passino E, Sgobio C, Bock J, Oostra BA, et al. Enriched Enviroment Promotes Behavioral and Morphological Recovery in a Mouse Model for The Fragile X Syndrome. PNAS, [Internet]. 2005. [citied 2012 August 01]; 102: 11557-62. Available from: http://www.pnas.org/.

24. Walker WA, Watkins JB, Duggan C. Nutrition in Pediatric. London: BC Decker Inc; 2003.p.388393, 540-547.

25. Maureen M Black. Zinc deficiency and child development. The American Journal of Clinical Nutrition. 1998.

26. Maureen M Black, Abdullah H Baqui, K Zaman. Iron and zinc Supplementation Promote Motor Development and Exploratory Behavior among Bangladeshi Infants. The American journal of clinical nutrition. 2004.

27. S.M Grantham, Mc. Gregor and C.C. Ani. The Role of Micronutrients in Psychomotor dan Cognitive Development. British Medical Bulletin; 55 (No 33): 511-527. 1999.

28. Harry J McArdle and Cheryl J Ashworth. Micronutrients in Fetal Growth and Development. Division of Nutrition, Pregnancy and Development, Rowett Research Institute, Aberdeen, UK. 2012. Available from: http://bmb.oxfordjournals.org.

29. Suriani Rauf, Faramitha. Pengaruh Pemberian Taburia terhadap Perubahan Statuz Gizi Anak Gizi Kurang Umur 12-24 Bulan di Kecamatan Pangkajene Kabupaten Pangkep Tahun 2010. Skripsi. Jurusan Gizi Poltekkes Kesehatan Kemenkes Makassar. 2012.

30. Shakur MS, Bano N. Effect of Zinc Supplementation on Appetite, Growth \& Body Composition in Children Suffering From NonSpecific Etiology of Feeding Refusal with Failure to Thrive. The ORION Medical Journal 2009 Jan;32(1):612-615.

31. Georgieff MK. Nutrition and Developing Brain: Nutrient Priorities and Measurement. Am J Clin Nutr. 2007; 85: 614S-20S.

32. Westermack T, Antila E. Diet in Relation to the Nervous System. In Garrow JS, James WP, Raplh A, editors. Human Nutrition and Dietetik. $10^{\text {th }}$ edition. New York: Chuchill Living Stone; 2000. 
33. E Pollitt, Husaini, M. A., Harahap, H., Halati, S., Nugraheni, A. and Sherlock, A. O. Stunting and Delayed Motor Development in Rural West Java. Am. J. Hum. Biol., 6: 627-635.1994.

34. Mahdin A. Husaini, Abas B. Jahari, Jajah K. Husaini, Yekti Widodo. Normal Motor Milestone Development for Use to Promote Child Care. Paediatrica Indonesiana. Vol. 50, No 6. 2010.

35. Jahari AB, Saco-Pollitt C. Effects of an Energy and Micronutrient Supplement on Motor Development and Motor Activity in Undernourished Children in Indonesia. The Europe journal of clinical nutrition. 2000.

36. L Kathleen Mahan and Sylvia Escott-Stump. Krause's Food and Nutrition Therapy. Canada: Saunders Elsevier. 2008.

37. Schauer C, Zlotkin S. Home fortification with Micronutrient Sprinkles - a New Approach for Prevention and Treatment of Nutritional Anemias. Paediatric Child Health 2003; 8: 87-90. 